\title{
Serological Study of Infection with the Chlamydia - Like Microorganism 'Simkania Negevensis' in Patients Undergoing Hemodialysis \\ George Emad Shaker ${ }^{1}$, Rehab Ahmed Rabie ${ }^{2}$, Ahmed Abo El-Makarem Hosny ${ }^{1}$, Heba Shafeak Abd El Khalik ${ }^{1}$ \\ Departments of ${ }^{1}$ Internal Medicine and ${ }^{2}$ Medical Microbiology and Immunology, Faculty of Medicine, Zagazig University, Egypt. \\ *Corresponding Author: Ahmed Abo El-Makarem Hosny, Mobile: (+20)01064448323, Email: Ak6457113@gmail.com
}

\begin{abstract}
Background: Infection is a common complication of hemodialytic treatment. Many of these infections are due to sepsis, primarily arising from the vascular access site. Simkania negevensis (S. negevensis) is an obligate intracellular bacterium belonging to the family Simkaniaceae in the Chlamydial order, which is able to survive and grow as an amoeba resisting microorganism in trophozoites and cysts of Acanthamoeba and other free-living protozoa, which probably represent its natural reservoirs.

Objective: The study aimed to early diagnose and minimize the risks of Simkania negevensis infection in hemodialysis patients.

Patients and Methods: This cross-sectional study was performed on 78 hemodialysis patients, and they were treated with regular hemodialysis. Patients were subjected to the following: complete history taking, full clinical assessment, laboratory investigation (complete blood count, measurement of serum IgG antibody against $\mathrm{S}$. negevensis in hemodialysis patients and water samples were collected from hemodialysis circuits for detection of the occurrence of S. negevensis infection).

Results: There was no significant difference in the age and gender between the patients undergoing hemodialysis with negative water samples for Simkania compared to hemodialysis with positive water for S. negevensis. Regarding hypertension (HTN) and diabetes mellitus (DM), there was no significant difference between the patients undergoing hemodialysis with negative water samples for Simkania compared to hemodialysis with positive water for S. negevensis. IgG levels are significantly higher in patients during hemodialysis when the water samples were positive for Simkania.

Conclusion: Our study detected the occurrence of S. negevensis in hemodialysis patients. When the patients were undergoing hemodialysis with positive water for Simkania, we detected significant rise of IgG antibodies against S. negevensis. Significant area under curve with significant cutoff $>6.1$ for IgG with sensitivity $73.3 \%$ and specificity $80.0 \%$.
\end{abstract}

Keywords: Hemodialysis, Serological Study, Simkania Negevensis.

\section{INTRODUCTION}

Chronic kidney disease (CKD) has been recognized as a worldwide public health problem, and the associated morbidity and mortality in patients reaching end-stage renal disease (ESRD) is constantly increasing. Infection is a common complication of hemodialytic treatment. It has been identified as the second cause of death among hemodialysis (HD) patients. Hospitalization for infection in the HD population has increased in the last decades ${ }^{(\mathbf{1})}$.

Many of these infections are due to sepsis, primarily arising from the vascular access site. Simkania negevensis (S. negevensis) is an obligate intracellular bacterium belonging to the family Simkaniaceae in the Chlamydial order, able to survive and grow as an amoeba resisting microorganism in trophozoites and cysts of Acanthamoeba and other free-living protozoa, which probably represent its natural reservoirs. S. negevensis was first defined in $1993^{(2)}$. It was found that not only the organism was able to replicate in Acanthamoeba, but it was also able to survive over long periods in amoeba cysts. Since free-living amoebae such as Acanthamoeba is found in many water sources, it may be the natural source of transmission of $\mathrm{S}$. negevensis to man.

Widespread human exposure to $\mathrm{S}$. negevensis has been reported in healthy subjects and in association with bronchiolitis in infants, both as communityacquired pneumonia and as an acute exacerbation of chronic obstructive pulmonary disease in adults. As suggested, it is possible that $\mathrm{S}$. negevensis infection may persist for a prolonged time in infected cells. Such persistence in respiratory or genital tracts could be associated with chronic inflammation, which may lead to scarring as described for C. Trachomatis ${ }^{(3)}$. The seropositivity to $\mathrm{S}$. negevensis in healthy population groups suggest that the organism is a simple colonizer ${ }^{(4)}$.

Angeletti et al. ${ }^{(5)}$ examined the occurrence of $\mathrm{S}$. negevensis in two HD population, characterized by high susceptibility to infectious complications. They detected for the first time the occurrence of $\mathrm{S}$. negevensis in hemodialysis and suggested that water used in hemodialysis could be one of the possible 
sources of S. negevensis infection, without clinical involvement risk for patients.

This study aimed to early diagnose and minimize the risks of Simkania negevensis infection in hemodialysis patients.

\section{PATIENTS AND METHODS}

This cross sectional study was performed at the Hemodialysis Unit of Al Mabara Health Insurance Hospital in Zagazig City from March to November 2020.

\section{Ethical approval:}

The study was approved by the Zagazig University Institutional Review Board (IRB), official permission from study setting department and an informed written consent was obtained from all patients before they joined the study.

This work has been carried out in accordance with the Code of Ethics of the World Medical Association (Declaration of Helsinki) for studies involving humans.

Seventy-eight hemodialysis patients were enrolled into the study, and they were treated with regular hemodialysis for at least three months. Total urea clearance $(\mathrm{Kt} / \mathrm{V})$ was measured to assess the adequacy of dialysis, and it was more than 1.2 in all hemodialysis patients. Exclusion criteria included patients with malignant tumors, patients with HIV infection and patients on immunosuppressant drugs.

All patients were subjected to routine laboratory investigations and specific investigations. The blood samples were drawn before dialysis.

Patients were subjected to the following:

a) Complete history taking

- Age of the patient.

- Sex.

- Respiratory diseases, gastroenteric disorders and history of antibiotic regimen prophylactic and therapeutic.

c) Laboratory investigations: 1) Complete Blood Count

- Specific investigation:
* Measurement of the patient's serum level of $\operatorname{IgG}$ antibody against Simkania negevensis was done by using a specific primer/probe mix (BROWN, USA).

- Assay Principle: This kit is used to assay the Immunoglobulin $\mathrm{G}(\mathrm{IgG})$ in the sample of human's serum, blood plasma, and other related tissue liquid.

* Water samples analysis: In our study, total of 8 water samples were collected from HD tap water in different occasions after the specific treatment of disinfection using the easy kit by using RNAse /DNAse free water (WHITE lid, USA) during the study time from March to November 2020.

In the first 4 months of our study when the water samples were negative for Simkania by using (Simkania positive control template (RED lid, USA), 39 patients were selected randomly, IgG antibodies were measured in their serum and the routine laboratory investigations were established for these patients. When the negative water samples turned positive, we measured the serum $\operatorname{IgG}$ for all the patients included in our study (78 patients), and the routine laboratory investigations were also established for all patients.

\section{Statistical Methods}

Data collected throughout history, basic clinical examination, laboratory investigations and outcome measures were coded, entered, and analyzed using Microsoft Excel software. Data were then imported into Statistical Package for the Social Sciences (SPSS version 20.0) software for analysis.

According to the type of data; qualitative were represented as number and percentage and were compared by Chi square test $\left(\mathrm{X}^{2}\right)$, while quantitative continuous data were represented by mean \pm SD (Standard deviation), median, and range and were compared by independent $\mathrm{t}$ test. $\mathrm{P}$ value was set at $<0.05$ for significant results and $<0.001$ for high significant result.

\section{RESULTS}

Age and sex of the studied patients are shown in table 1.

Table (1): Age and sex distribution among studied group

\begin{tabular}{|c|c|c|c|}
\hline 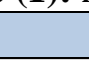 & & \multicolumn{2}{|c|}{ Age (years) } \\
\hline & & \multicolumn{2}{|c|}{$46.71 \pm 10.61$} \\
\hline \multirow{2}{*}{\multicolumn{2}{|c|}{ Median (Range) }} & \multicolumn{2}{|c|}{$50.0(23-67)$} \\
\hline & & $\mathbf{N}$ & $\%$ \\
\hline \multirow[t]{3}{*}{ Sex } & Male & 69 & 88.5 \\
\hline & Female & 9 & 11.5 \\
\hline & Total & 78 & 100.0 \\
\hline
\end{tabular}

History of some chronic diseases of the patients is shown in table 2. 
Table (2): Medical history of the patients

\begin{tabular}{|c|c|c|c|}
\hline \multicolumn{2}{|c|}{} & $\mathbf{N}$ & $\%$ \\
\hline Diabetes mellitus & No & 40 & 51.3 \\
\cline { 2 - 4 } & Yes & 38 & 48.7 \\
\hline Hypertension & No & 59 & 75.6 \\
\hline Respiratory diseases & Yes & 19 & $\mathbf{2 4 . 4}$ \\
\hline (asthma, chronic obstructive pulmonary diseases) & No & 71 & $\mathbf{9 1 . 0}$ \\
\cline { 2 - 4 } & Yes & 7 & 9.0 \\
\hline
\end{tabular}

Eight water samples were collected from hemodialysis water from March to November 2020, two samples of them were positive for Simkania. During nine months of the study time, the water samples distribution was as follow: The $1^{\text {st }}, 3^{\text {rd }}$ and fourth months; the water samples for Simkania were negative. The $5^{\text {th }}, 6^{\text {th }}$ months; 2 water samples for Simkania turned positive. The last 3 months $7^{\text {th }}, 8^{\text {th }}$ and $9^{\text {th }}$, the water samples taken turned negative.

Simkania positive founded in $25 \%$ of studied samples (Table 3 ).

Table (3): Simkania Negevensis in water samples

\begin{tabular}{|c|c|c|c|}
\hline \multicolumn{2}{|c|}{} & $\mathbf{N}$ & $\%$ \\
\hline \multirow{3}{*}{ Simkania in water sample } & - VE & $\mathbf{6}$ & $\mathbf{7 5}$ \\
\cline { 2 - 4 } & + VE & $\mathbf{2}$ & $\mathbf{2 5}$ \\
\cline { 2 - 4 } & Total & $\mathbf{8}$ & $\mathbf{1 0 0 . 0}$ \\
\hline
\end{tabular}

There was no significant difference between groups regarding hemoglobin (Table 4).

Table (4): Hemoglobin in patients undergoing hemodialysis with negative water samples for Simkania compared to hemodialysis with positive water for Simkania

\begin{tabular}{|c|c|c|c|c|}
\hline Blood tests & \multicolumn{2}{|c|}{ Water sample test for Simkania } & \multirow{2}{*}{ t/ $\mathbf{X}^{\mathbf{2}}$} & \multirow{2}{*}{$\mathbf{P}$} \\
\cline { 1 - 3 } & $\begin{array}{c}-\mathrm{VE} \\
(\mathbf{n}=\mathbf{3 9} \text { patients })\end{array}$ & $\begin{array}{c}+\mathrm{VE} \\
(\mathbf{n}=\mathbf{7 8} \text { patients })\end{array}$ & & \\
\hline Hemoglobin (HB) $\mathbf{g} / \mathbf{d L}$ & $\mathbf{9 . 8 8} \pm \mathbf{0 . 2}$ & $\mathbf{1 0 . 3} \pm \mathbf{0 . 1 8}$ & $\mathbf{1 . 3 3 9}$ & $\mathbf{0 . 1 8 5}$ \\
\hline
\end{tabular}

IgG levels are significantly higher in patients during hemodialysis when the water samples were positive for Simkania (Table 5).

Table (5): Comparison between patients during hemodialysis with Simkania positive and negative water samples regarding IgG levels

\begin{tabular}{|c|c|c|c|c|}
\hline & \multicolumn{2}{|c|}{ Water sample test for Simkania } & \multirow{2}{*}{ t/ Mann Whitney } & P \\
\cline { 2 - 3 } & - VE & + VE & & \\
\hline IgG (mg/mL) & $\mathbf{4 . 0 6} \pm \mathbf{0 . 8 1}$ & $\mathbf{7 . 5 2 \pm 0 . 9 5}$ & $\mathbf{4 . 1 7 9}$ & $\mathbf{0 . 0 0} * *$ \\
\hline
\end{tabular}

Significant area under curve was 0.77 and the cutoff point was $>6.1$ for IgG.

Table (6): Area under the curve (AUC), cutoff, and validity.

\begin{tabular}{|c|c|c|c|c|c|c|c|}
\hline \multirow{2}{*}{$\begin{array}{l}\text { Test Result } \\
\text { Variable(s) }\end{array}$} & \multirow{2}{*}{$\begin{array}{c}\text { Area } \\
\text { under the } \\
\text { curve }\end{array}$} & \multirow{2}{*}{$\begin{array}{l}\text { Cutoff } \\
\text { point }\end{array}$} & \multirow[t]{2}{*}{$\mathbf{P}$} & \multicolumn{2}{|c|}{ 95\% Confidence Interval } & \multirow[t]{2}{*}{ Sensitivity } & \multirow[t]{2}{*}{ Specificity } \\
\hline & & & & $\begin{array}{l}\text { Lower } \\
\text { Bound }\end{array}$ & Upper Bound & & \\
\hline $\begin{array}{c}\text { IgG } \\
(\mathrm{mg} / \mathrm{mL})\end{array}$ & 0.770 & $>6.1$ & $<0.01 * *$ & 0.645 & 0.895 & $73.3 \%$ & $80.0 \%$ \\
\hline
\end{tabular}

Significant area under curve with significant cutoff $>6.1$ for IgG with sensitivity $73.3 \%$ and specificity $80.0 \%$

\section{DISCUSSION}

In our study we investigated the occurrence of S. negevensis infection in the hemodialysis patient. According to our study, total of 8 water samples were collected from HD tap water in different occasions after the specific treatment of disinfection from March to November 2020. Two positive water samples were found from total of eight water samples. This is probably due to lack of proper periodic disinfection procedures in water treatment system. But in the study of Angletti et al. ${ }^{(5)}$ they collected the water samples; half of them from tap sited before specific treatment of disinfection and a half of them after specific treatment of disinfection. They found a higher seroprevalence of antibodies against Simkania negevensis in the hemodialysis patients, compared to renal transplant patients (IgG 22\% vs 9\% - IgA 9\% vs 3\%). S. negevensis was isolated in all water samples analyzed. They detected for the first time the occurrence of $\mathrm{S}$. negevensis in hemodialysis and in renal transplant patients. Our findings suggest that water used in hemodialysis could be one of the possible sources of S. negevensis infection, without clinical involvement risk for patients. During the 
study time from March to November, the water samples distribution was as follow: The $1^{\text {st }}, 3^{\text {rd }}$ and fourth months; the water samples for Simkania were negative. The $5^{\text {th }}$, $6^{\text {th }}$ months; 2 water samples for Simkania turned positive. The last 3 months $7^{\text {th }}, 8^{\text {th }}$ and $9^{\text {th }}$, the water samples taken turned negative.

IgG levels were significantly higher in patients during hemodialysis when the water samples were positive for Simkania Significant area under curve with significant cutoff $>6.1$ for $\mathrm{IgG}$ with sensitivity $73.3 \%$ and specificity $80.0 \%$. This agree with the result of Donati et al. (4) study that demonstrated remarkable differences in serum IgG rates against $S$. negevensis and that infection with Simkania.

This agrees with the study of Angletti et al. (5) that demonstrated a high prevalence of $\mathrm{IgG}$ antibodies to $S$. negevensis in patients undergoing chronic hemodialysis. This agrees with also with Yamaguchi $\boldsymbol{e t}$ al. ${ }^{(6)}$

The prevalence and pathogenic potential role of $S$. Negevensis in renal transplant (RT) recipients and in HD patients is still unknown. $\operatorname{Ig} \mathrm{A}$ and $\mathrm{IgG}$ antibodies are antibodies produced by the immune system as a response to the infection with $S$. Negevensis. This investigation was prompted by previous $S$. Negevensis detection in water sources and by its relative resistance to chlorination procedures used for routine treatment of drinking water supplies ${ }^{(7) .}$

Regarding age and sex of the studied group, mean age was 46.71 and most cases were males. There was no significant difference in the age and gender between the patients undergoing hemodialysis with negative water samples for Simkania compared to hemodialysis with positive water for S. Negevensis. This is in contrast to the study of AL-Younes and Paldanius ${ }^{(8)}$ which was performed in Jordan, the study demonstrated a possible relationship between gender and the prevalence of the bacterial infection of Simkania.

Regarding HTN and DM distribution among studied groups, there was no significant difference between the patients undergoing hemodialysis with negative water samples for Simkania compared to hemodialysis with positive water for S. negevensis. Hemoglobin level is the most specific parameter used to establish the presence and severity of anemia in hemodialysis patients ${ }^{(9)}$. Hematocrit level is not assessed because it is a relatively unstable parameter and lack standardization (10).

There was no significance in our study regarding hemoglobin between patients who were undergoing hemodialysis with positive and negative water samples for Simkania. This agrees with results of Angletti et al.
(5) study that detected no statistically difference according to hemoglobin and routine investigations in patients and found no relation with the prevalence of the infection of Simkania.

The water that is used in hemodialysis may be involved as a possible source of S. negevensis infection. Mostly important, the forced continuous contact of the HD subjects with $\mathrm{S}$. negevensis could represent one of the several factors, not fully known, implicated in the uremic inflammation $^{(5)}$.

\section{CONCLUSION}

Our study detected the occurrence of S. negevensis in hemodialysis patients. When the patients were undergoing hemodialysis with positive water for Simkania, We detected significant rise of $\mathrm{IgG}$ antibodies against $\mathrm{S}$. negevensis and significant area under curve with cutoff point $>6.1$ for IgG with sensitivity of $73.3 \%$ and specificity of $80.0 \%$.

\section{REFERENCES}

1. Mills K, Xu Y, Zhang W et al. (2015): A systematic analysis of worldwide population-based data on the global burden of chronic kidney disease in 2010. Kidney Int., 88(5):950-7.

2. Kahane S, Dvoskin B, Mathias M et al. (2001): Infection of Acanthamoeba polyphaga with Simkania negevensis and S. negevensis survival within amoebal cysts. Appl Environ Microbiol., 67(10):4789-95.

3. Hornung S, Thuong B, Gyger J et al. (2015): Role of Chlamydia trachomatis and emerging Chlamydia - related bacteria in ectopic pregnancy in Vietnam. Epidemiol Infect., 143:2635-8.

4. Donati M, Fiani N, Di Francesco A et al. (2013): $\operatorname{IgG}, \operatorname{Ig} A$ response to Simkania negevensis in sera of patients with respiratory and gastrointestinal symptoms. New Microbiol., 36(3): 3036-43

5. Angeletti A, Biondi R, Battaglino $G$ et al. (2017): Seroprevalence of a "new" bacterium, Simkania negevensis, in renal transplant recipients and in hemodialysis patients. BMC Nephrology, 18: 133-140.

6. Yamaguchi T, Yamazaki T, Inoue M et al. (2005): Prevalence of antibodies against Simkania negevensisin a healthy Japanese population determined by the microimmunofluorescence test. FEMS Immunology \& Medical Microbiology, 43(1): 21-27.

7. Jamal A, Resende M, Prochnow T et al. (2015): Simkania negevensis and acute cellular rejection in lung transplant recipients. Clin Transplant., 29(8):705-11.

8. Al-Younes H, Paldanius M (2014): High seroprevalence of Simkania negevensis in Jordan. Brazilian Journal of Microbiology, 45(4):1433-7.

9. Tran L (2002): Correction of hemoglobin and outcomes in renal insufficiency (CHOIR): study design. Am J Kid Dis., 39(4): 27-33.

10. Brittin G, Brecher G, Johnson C (1969): Stability of blood in commonly used anticoagulants. Use of refrigerated blood for quality control of the Coulter Counter Model S. Am J Clin Pathol., 52:690-694. 